\title{
Induction of defence reactions in plants
}

\author{
HANS THORDAL-CHRISTENSEN, PER L. GREGERSEN, JAN B. ANDERSEN, \\ and VIGGO SMEDEGAARD-PETERSEN
}
Department of Plant Pathology, The Royal Veterinary and Agricultural University, Thorvaldsensvej 40, 1871 Frederiksberg C, COPENHAGEN, Denmark

\begin{abstract}
Induced local resistance presumably involves the same mechanisms in the plants as resistance elicited during normal plant-pathogen interactions. In many cases resistance elicitors from pathogens have been found to be non-specific, i.e. unrelated to race-cultivar specificity. Thus, existence of specific resistance suppressors has been suggested to make the virulent races able to infect. In other cases specific resistance elicitors have been indicated to exist in avirulent races, by which the race specific resistance may be accomplished.

At our Department resistance has been induced in the barley - powdery mildew interaction by use of double inoculation procedures. Both virulent and avirulent races of barley powdery mildew can induce resistance, but avirulent races show an increased resistance induction ability in relation to virulent races from 12 hours after inoculation. In barley plants wheat powdery mildew induced more resistance than barley powdery mildew 1 to 8 hours after inoculation. Induced resistance was mainly localized to the epidermal cells attacked by the inducer, but an effect was also present in the surrounding epidermal cells.

The energetic consequences of resistance in barley to barley powdery mildew have been found to be reflected in an increased respiratory rate at the time of infection attempt. Further, these energy costs appeared to reduce grain yield by $7 \%$.

The experession of resistance in barley is thought to involve de novo synthesis mRNAs and proteins, which makes it possible to apply gene technological methods to study induced resistance. Research of this kind is in progress at our Department, which hopefully will give information on the mechanisms of resistance triggering and resistance expression.
\end{abstract}

Index words: barley, powdery mildew, induced resistance

\section{Introduction}

Induced resistance can be defined as active defence based on physical and chemical barriers elicited by preliminary inoculation with pathogens or non-host pathogens, or by application of metabolic products from such organisms. It acts against subsequent infection by otherwise pathogenic organisms. In a broader sense the term also includes resistance induced by abiotic stimuli.

Distinction can be made between two functionally different forms of induced resistance, systemic and local. Induced systemic protec- 
tion against a pathogen can be elicited by previous inoculation of the host with either avirulent or virulent races of the same pathogen or with non-host pathogens. The resistanceinducing factor is translocated from the site of induction to other, usually younger plant parts, where it conditions the host tissue to respond in a resistant fashion upon subsequent challenge by a pathogen. In contrast to systemic protection, induced local resistance is restricted to the site of inducer inoculation, and until recently only avirulent races of a pathogen and non-host pathogens have been shown to act as inducers. This article will only deal with aspects of induced local resistance, and does not intend to cover induced systemic resistance.

Presumably induced resistance, as it results from double inoculation, involves the same basic defence elements as known from ordinary incompatible host-pathogen interactions or from non-host resistance: recognition, rapid elicitation or sensitation towards a resistant stage, and subsequent accumulation of resistance-related metabolites. One of the exiting aspects of induced resistance is, however, that it seems to constitute a suitable model for detailed studies of the molecular basis of disease resistance by the employment of DNA techniques.

Induced, active resistance involves drastic changes in the metabolic activity around the site of attempted infection such as rapid cytoplasmatic movement, synthesis and deposit of heterogeneous materials around the attempted penetration sites, changes in respiration and photosynthesis, and the accumulation of secondary fungitoxic metabolites. Research at our Department has shown that such highly energy-consuming defence reactions occur at the expense of host energy resources and therefore finally lead to reduction in plant growth and yield.

\section{Elicitation of defence reactions in plants}

At the macroscopic level induced resistance appears as the end-result of a complex process involving extensive metabolic changes in the plant tissue (see a later chapter about molecular studies of resistance). It is, however, difficult to establish the sequence of events in this process following application of the inducer and challenger agents. Here, we will consider the efforts done to elucidate the first steps in the inducing process, also called the determinative phase as opposed to the subsequent expressive phase (KEEN 1982). The term elicitation used in this text covers the putative decisive events taking place in these first steps of interactions between hosts and pathogens. The question to be raised is: What are the primary events at the biochemical level responsible for the extensive changes involved in induction of defence reactions in plants?

\section{Elicitors of defence reactions}

The term elicitor has been used for several years to designate substances which signal the plant to trigger defence responses. Especially the term has been applied when dealing with phytoalexin accumulation (DARVILL and AL BERSHEIM 1984). This somehow complicates the matter because phytoalexin accumulation in many cases has been regarded as essential to resistance and this is not always the case. For instance ROHWER et al. (1987) showed that potato leaves are able to react with a strong resistance response without accumulating detectable amounts of phytoalexins.

Therefore, the work that has been done with elicitors in different systems is in some ways incommensurable because of the different methods applied, but still, it casts a good light on the biochemical interactions between hosts and pathogens at the initial stages of infection.

The elicitors described in the literature are either biotic, i.e. originating in plant or pathogen, or of abiotic origin (DAvIS et al. 1986).

\section{Elicitors of fungal origin}

Most of the extensive work trying to iso- 
late substances of fungal origin which, when applied in purified form, trigger defence responses in plants, has been done with soybean, bean and potato.

In soybean it has been shown that fractions isolated from the cell walls of Phytophthora megasperma f.sp. glycinea $(\mathrm{Pmg})$ provoke the accumulation of phytoalexins when applied to cotyledons of soybean (DARVILL and ALBERSHEIM 1984). One elicitor-active substance from this cell wall fraction was purified by ShARP et al. (1984) and characterized as a $\beta$-glucan. Apparently the elicitor activity of the glucan is related to the specific arrangement of branch points because other glucans, similar in chemical composition but with other arrangements of branch points, were inactive.

The elicitors from cell walls of Pmg are race-non-specific, i.e. they work independently of the interaction between soybean cultivars and races of $P m g$ as described by the genefor-gene model. Thus elicitors isolated from avirulent races elicit as much phytoalexin accumulation as the ones isolated from virulent races (AŶ́RS et al. 1976).

In the interaction between potato and Phytophthora infestans $(\mathrm{Pi})$, Bоsтоск et al. (1981) showed that unsaturated fatty acids, especially eicosapentaenoic and arachidonic acid, from the cell walls of $\mathrm{Pi}$ were able to elicit a hypersensitive response, accompanied by phytoalexin accumulation, in potato tuber tissue. This elicitation was also non-specific, i.e. unrelated to race-cultivar specificity. Furthermore, it has been shown that the elicitor activity of the fatty acids is enhanced by combining them with glucans from the cell walls of Pi (Preisig and Kuc 1985). The glucans themselves are inactive as elicitors of the hypersensitive response.

The non-specificity of elicitors requires additional explanation concerning the biochemical determination of race-specific interactions. Such an explanation has been suggested for the potato- $P i$ interaction, where race-cultivar specificity, defined by the $\mathrm{R}$-genes in potato cultivars, is ascribed to the existence of fungal suppressors of the hypersensitive reaction (DOKE et al. 1979). The suppressors are supposed to work by specifically hindering the response to the non-specific elicitors in compatible host-pathogen interactions (DOKE et al. 1987). The mechanisms of this suppression are totally unknown.

Another theory concerning race-cultivar specificity postulates the existence of racespecific elicitors as opposed to the non-specific elicitors suggested for $\mathrm{Pmg}$ and $\mathrm{Pi}$. ANDERSON (1980), working with Colletotrichum lindemuthianum $(\mathrm{Cl})$ on bean, suggested the existence of such specific elicitors. She used three races of $\mathrm{Cl}$ with different virulence characters to show that the elicitor activity of extracellular components obtained from liquid cultures of the three races correlated well with their virulence characters. This work was extended by TePPER and ANDERSON (1986) who showed that two cultivars of bean displayed differential responses to extracellular components of $\mathrm{Cl}$. Although the results were not entirely consistent with race-cultivar specificity, they contribute to a more thorough understanding of the events taking place in the interphase between the invading pathogen and the host tissue. Intuitively, extracellular/surface bound substances are more likely to play a role here than substances obtained from homogenates of fungal cell walls.

\section{Elicitors originating in plants}

In several cases it has been shown that plant tissues within the cell walls possess socalled endogenous elicitors which, after being released, are able to elicit the accumulation of phytoalexins indicative of a defence reaction (Darvill and Albersheim 1984).

Hargreaves and Bailey (1978) showed that the contact with dead cells caused living bean cells to produce phytoalexins, which was ascribed to the release of an elicitor from the dead cells. HAHN et al. (1981) showed that a fraction from soybean cell walls was active as elicitor and that it contained oligosaccharides rich in galacturonic acid. The existence of endogenous elicitors containing 
galacturonic acids from the pectic fragments of cell walls was also shown by BRUCE and WEST (1982) in castor bean. These authors suggested that the endogenous elicitor could be released upon infection with a pathogen because of a fungal endogalacturonase working in the cell wall degradation process associated with infection attempts.

The existence of endogenous elicitors is in accordance with theories about cell wall oligosaccharides being involved in many different physiological control processes as a new kind of regulatory molecules (FRY 1986). The hypothesis is that such cell wall oligosaccharides under appropriate conditions can be released from their built-in state, for instance during degradation of the cell wall by invading pathogens.

\section{Elicitors and elicitation}

Most of the experiments concerning elicitors, which have been considered in this text, have been carried out with elicitors applied to plant tissue in a more or less purified form. This gives rise to some problems when trying to relate the results from the experiments to the events actually taking place in the interface between pathogen and host tissue during the infection process. It is difficult to infer anything conclusive about the role of the isolated elicitors under in vivo conditions. There, they necessarily will have to function in intimate contact with many other compounds of both plant and pathogen origin. One could get the idea that elicitors isolated by more or less harsh procedures could turn out to be artefacts of these procedures, and that they could be acting more like abiotic elicitors rather than as biotic elicitors relevant to the system under study. The results by Preisig and Kuc (1985) showing that elicitor active fatty acids interact with non-eliciting glucans illustrates the complexity of systems comprising more than just one component. The triggering of defence responses is probably more complicated than what the action of one single elicitor can account for.

\section{How does elicitation function?}

The working hypothesis about the function of elicitors in triggering defence responses implies a release of fungal elicitors from the invading pathogen and a subsequent reaction by the plant tissue resembling those obtained when elicitors are applied in purified form (Darvill and Albersheim 1984). To a certain extent such a hypothesis is supported by the observations that enzymes from plant tissues are able to release elicitor-active substances from fungal cell walls and perhaps thereby promote the induction of defence responses (Keen and Yoshikawa 1983).

After the release it is hypothesized that an interaction takes place between the elicitor and a receptor in the host tissue. YoshiKawa et al. (1983) conclude to have found such a receptor site on the membrane of soybean cells. This conclusion is based on the observed specific binding of the elicitor from Pmg to membrane fragments from soybean. The receptor has not been characterized any further and it is not explained how the observed binding is able to transfer a signal to the host cell ordering a defence response to be triggered. However, Yoshikawa et al. (1983) suggest that receptors, like the one observed, may exhibit racespecific properties and thereby account for the race-cultivar interactions observed in many host-pathogen systems.

EPPERLEIN et al. (1986) suggest an action of abiotic elicitors which gives a causal explanation of elicitor action at the physiological level. $\mathrm{AgNO}_{3}$ and $\mathrm{HgCl}_{2}$ were used as elicitors and the results suggested that the activity of these agents was mediated by the generation of $\mathrm{OH}$ in the treated tissue. The heavy metal salts are able to initiate redox-reactions which lead to the $\mathrm{OH}$-generation. Once generated, this reactive oxygen species is able to initiate lipid peroxidation in the membranes which can continue as an autoxidative chain reaction leading to perturbation of membrane function.

EPPERLEIN et al. (1986) put up the following sequence of events as a model for the function 
of elicitors: Free radical generation $\rightarrow$ lipid peroxidation $\rightarrow$ diffusion of endogenous elicitor $\rightarrow$ derepression of genes required for phytoalexin synthesis. They argued that some of the biotic elicitors mentioned earlier in this text could act in a similar way. For instance, eicosapentaenoic and arachidonic acids are known to undergo spontaneous peroxidation in the presence of $\mathrm{O}_{2}$ and they might thereby start the listed events leading to phytoalexin accumulation.

The theory by EPPERLEin et al. (1986) is supported by the work of DOKE (1983), who observed a marked generation of reactive oxygen species around sites where $P$. infestans attempted infection into potato tuber tissue. This reaction was related to the incompatible interaction between host and pathogen. CHAI and DOKE (1987) extended this work and found a small race-non-specific elicitation of $\mathrm{O}_{2}^{-}$generation in potato leaves at an early time after inoculation with $\mathrm{Pi}$. In the incompatible interaction this was followed by a marked increase in $\mathrm{O}_{2}^{-}$generation, similar to that found in potato tuber tissue, while in the compatible interaction the initial $\mathrm{O}_{2}^{-}$generation faded away. The theory that reactive oxygen species might initiate membrane damage is also supported by other studies showing that peroxidation of lipids in the membranes is involved in early hypersensitive responses to pathogens (STElzig et al. 1983, OCAMPo et al. 1986).

The model that appears from these observations suggests that elicitation of defence reactions might depend on the initiation of an autoxidation of lipid components in the host plasmalemma followed by a derangement of the membrane. From the deranged membrane a signal could be transferred to the metabolic and genetic apparatus of the cell, telling that something is wrong and that a reaction has to be put up. That the membrane functions as a mediator of the signal could explain why defence responses often are localized right below the infection site in the shape of e.g. papillae.
This model for elicitation of defence reactions involving membrane derangement by reactive free radicals does not give any suggestions as to how race-specificity is working in host-pathogen interactions. In some way the pathogen in compatible interactions must be able to prevent or suppress the development of the defence response.

Under in vivo conditions a subtle balance exists between pathogen and host when infection is attempted. Even in compatible interactions many infection attempts run the risk of failure. Among others, ANDERSEN and TORP (1986) have shown this for barley-powdery mildew interaction. This could mean that just a slight perturbation of the infection process might tip over the subtle balance in favour of the host. Race-specific elicitation of defence reactions could be caused by "constitutive" perturbation of the infection process, perhaps working via interference with the coalescence between the infection hypha and the host cell wall. RAA et al. (1977) noted that such an association apparently is essential for pathogens. Improper coalescence could - from the host cells point of view - be taken as a rather aggressive wounding and this could cause a defence response to be induced. RAA et al. (1977) noted that non-host pathogens apparently are unable to attach firmly to plants and this supports the idea that coalescence with the host cell wall is essential for a successful infection.

Unfortunately we do not know very much about elicitation of defence reactions in monocotyledons even though host-pathogen interactions with monocotyledenous hosts have been characterized rather well in genetic analysis (EllingBoe 1982). The latter will, however, be very helpful when trying to get into more details concerning the elicitation events because hypothesized molecular mechanisms can be compared to the results of genetic analysis. The time course studies conducted with induced resistance in the barley-powdery mildew interaction (see the next part) may also be useful tools in elucidating the initial events taking place in resistant reacting tissue, 
especially when combined with molecular investigations of the same interactions.

\section{Induced resistance in barley-powdery mildew interaction}

Induced resistance in the barley - powdery mildew interaction has been studied extensively during the last 15 years. In some experimental procedures the inducer race remained on the barley leaf surface after challenge inoculation, and distinction between inducer and challenger was made possible by testing only avirulent and non-pathogenic races as inducer. It was shown that avirulent (ANDERSEN 1983, Chaudhary et al. 1983, Chin et al. 1984) and non-pathogenic (KUNOH et al. 1985) races of powdery mildew were able to induce resistance in barley. ANDERSEN (1983) found that $30 \mathrm{~min}$. between inoculation with the avirulent inducer and the virulent challenger was sufficient to reduce the number of challenger colonies.

Ouchi et al. (1974 and 1976) introduced removal of the inducer after the induction period. This technique allowed the test of virulent inducer races as well. Studies of the resistance inducing ability of virulent and avirulent barley powdery mildew races showed that only avirulent races induced resistance in 24 and 48 hours (OucHI et al. 1974). Further, it was found that wheat powdery mildew was able to induce resistance after an induction period of 6 hours (OucH et al. 1976).

Cho and SmedegaArd-Petersen (1986) and Thordal-Christensen and SmedegaArd-PeTERSEN (in press) quantified the effect of inducer race, induction period, and inducer density. Inoculations were made on the first leaves of isogenic lines of the barley cultivar "Pallas». The leaves were fixed in horizontal position while still attached to the barley plants. After the induction periods the inducers were removed by rubbing the leaves with wet cotton balls. Challenge inoculations were performed, and the induced resistance was later assessed as percentage reduction in number of colonies developed by the virulent challenger race in relation to a non-induced control.

The shortest induction period in which resistance was induced by barley powdery mildew was found to be 0.5 hours ( $\mathrm{CHO}$ and SMEDEGAARD-Petersen 1986) (Fig. 1) and 2 hours (Thordal-Christensen and SmedegaARd-PeTERSEN (in press) (Fig. 2). In apparent dis-

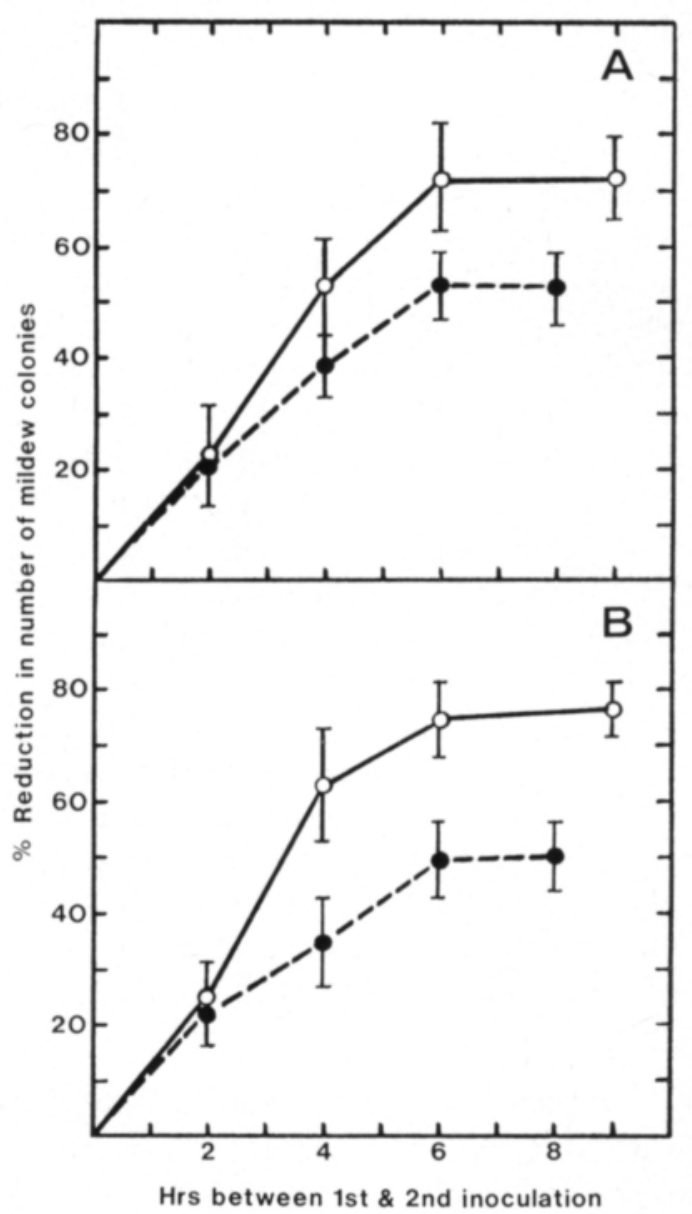

Fig. 1. The influence of inducer-inoculum density on the induction of resistance against subsequent infection by Erysiphe graminis f.sp. hordei. A, Near-isogenic line of the barley cultivar Pallas with resistance gene $\mathrm{Ml}-\mathrm{a}$, inducer race $\mathrm{H} 21$ (avirulent), challenger race A6 (virulent). B, Nearisogenic line of the barley cultivar Pallas with the resistance gene $\mathrm{Ml}-\mathrm{a} 13$, inducer race $\mathrm{H} 21$ (virulent), challenger race $\mathrm{H} 21$ (virulent). Symbols: $\bullet-\cdots \bullet$, inoculum density 20 conidia $/ \mathrm{mm}^{2}$; o- o, inoculum density 200 conidia $/ \mathrm{mm}^{2}$. Inducer inocula were removed immidiately before the challenge inoculation were made. (From Cho and Smedegaard-Petersen 1986). 

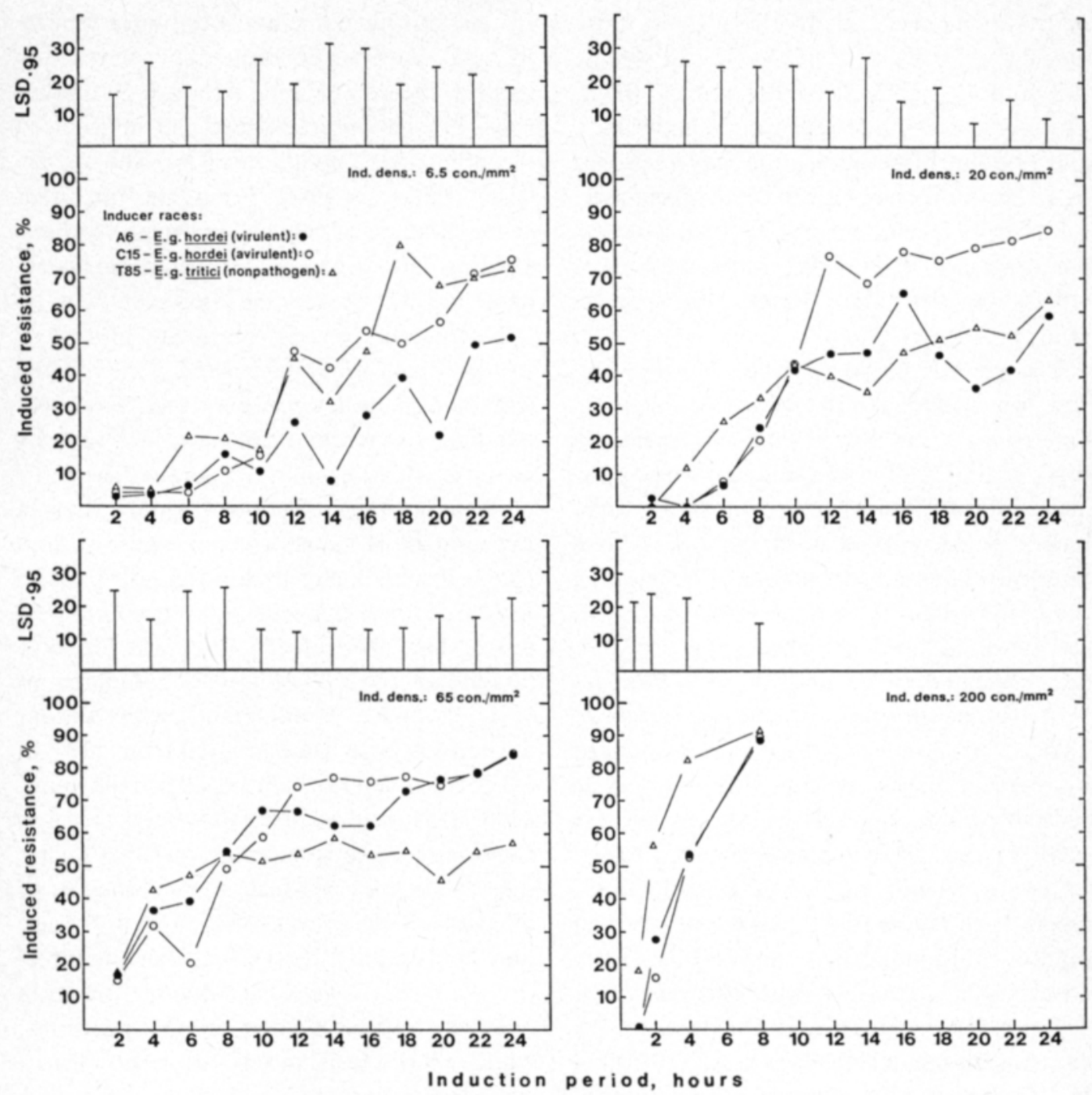

Fig. 2. Comparison of the resistance induced in a near-isogenic line of the barley cultivar Pallas with the resistance gene Ml-a. Resistance was induced by the virulent race A6, and the avirulent race C15 of Erysiphe graminis f.sp. hordei, and by the non-pathogenic race T85 of E. graminis f.sp. tritici. The comparison was made at four different inducer densities and in 13 different induction periods. Mean values of three replications. (From Thordal-Christensen and Smedegaard-Petersen in press, a).

agreement with the results of OucH et al. (1974), it was found that virulent and avirulent races of barley powdery mildew showed the same ability to induce resistance in barley in induction periods of up to 10 hours (Figs. 1 and 2). Our results of induced resistance up to 10 hours after inoculation are in agreement with the findings that resistance elicitors are often non-specific (AYERS et al. 1976, BosTOCK et al. 1981, RoHwer et al. 1987).
However, when the induction period was extended to $12-24$ hours (Fig. 2) the resistance induced by the avirulent race was increased significantly in relation to that induced by the virulent race. This difference, only present at relatively low inducer densities, agrees with the results of OucHI et al. (1974), except that significant resistance induction by the virulent race in induction periods of $12-24$ hours was found (Fig. 2). The time of the establishment 
of the difference, i.e. 10 to 12 hours after inoculation, coincides with the time of specific recognition suggested by ElLiNGBoE (1972). The increase of induced resistance between 10 and 12 hours after inoculation may be caused by an elicitor present only in the avirulent race. Existence of specific elicitors has been indicated by Anderson (1980), Keen and Legrand (1980), De WIT et al. (1986), and Mayama et al. (1986).

The non-host pathogen, wheat powdery mildew, was included in the studies of THORDALChristensen and Smedegaard-Petersen (in press, a) (Fig. 2). It was found that wheat powdery mildew induced more resistance than barley powdery mildew in the first 6 to 8 hours after inducer inoculation. Disregarding the inducer density of 6.5 conidia $/ \mathrm{mm}^{2}$, the resistance induced by wheat powdery mildew appeared to be insensitive to changes in the induction period between 10 and 24 hours. This is similar to resistance induced by virulent barley powdery mildew, while resistance induced by avirulent barley powdery mildew increased significantly between 10 and 12 hours of induction at 20 conidia $/ \mathrm{mm}^{2}$. OucH et al. (1976) found that wheat powdery mildew could induce resistance 6 hours after inoculation, consistent with the results of Thordal-Christensen and SmedegaARd-PETERSEN (in press, $a$ ). ROHWER et al. (1987) has in agreement with the rapid induction of resistance by wheat powdery mildew found that the non-host pathogen Phytophthora megasperma f.sp. glycinea induced rishitin accumulation in potato tuber earlier than the pathogen Phytophthora infestans.

\section{Infection efficiency and induced resistance by a virulent race}

In preliminary experiments with single inoculation procedures it was found that the infection efficiency of a virulent race was reduced when the inoculum density was increased. This effect and the effect of resistance induced by a virulent race, assessed in a double inoculation procedure, are considered to be caused by the same phenomenon. Resistance appears in both cases to be elicited by and acting against the same virulent powdery mildew race. Further, as resistance can be induced 0.5 hour after inoculation (CHO and SMEDEGAARD-PETERSEN 1986), it may be functional at the moment of cell wall penetration about 10 hours later in the single inoculation procedure, and hence reduce the infection efficiency.

To compare these effects an inoculum density gradient was constructed with a virulent race of barley powdery mildew (THORDal-Christensen and SmedegaArd-Petersen in press, a). At each inoculum density of the gradient both the infection efficiency assessed as number of haustoria per appressorium (single inoculation procedure) and the induced resistance (double inoculation procedure) were tested. The infection efficiency was found to be reduced from $97 \%$ at 0.20 conidia $/ \mathrm{mm}^{2}$ to $11 \%$ at 6.5 conidia $/ \mathrm{mm}^{2}$, while the induced resistance was increased from $23 \%$ at 6.5 conidia $/ \mathrm{mm}^{2}$ to $80 \%$ at 200 conidia $/ \mathrm{mm}^{2}$. Thus the inoculum density needed to cause $50 \%$ induced resistance was 40 times higher than the density at which $50 \%$ reduction of infection efficiency was found. This difference may be explained by the fact that the infection efficiency is assessed when the infection units are located in their original positions, while induced resistance is assessed by use of a challenger, located in random positions different from those where the resistance actually was induced.

Correlation between induced resistance and host fluorescence at the site of the inducer

In a later work (THORDAL-CHRISTENSEN and SmedegaARd-Petersen in press, $b$ ) inducer fluorescence (host fluorescence at the site of the inducer) was investigated in the barley powdery mildew interactions. A fluorescent halo appeared in the epidermal cell at the site of primary germ tubes of the inducer conidia. The diameter of the halo was 2 and $4 \mu \mathrm{m}$ five hours after inoculation with barley and wheat powdery mildew, respectively. 10 hours after 
inoculation the fluorescent haloes had doubled their diameter, and fluorescent papillae had developed in the center of the haloes. At this time the diameters of the papillae at the site of barley powdery mildew were about $3 \mu \mathrm{m}$ and of the site of wheat powdery mildew it was $5 \mu \mathrm{m}$. The diameter of these fluorescent papillae at the site of the primary germ tube only increased slightly until 24 hours after inoculation. Ten hours after inoculation, inducer fluorescence (fluorescent haloes and papillae) at the appressorial lobes had only developed to a small extent, but in the case of barley powdery mildew it developed considerably in the next 14 hours. In the case of wheat powdery mildew, inducer fluorescence at the site of the appressorial lobes only had a weak development in this period.

When comparing the two assessments of host response to powdery mildew infection, i.e. induced resistance (Figs. 1 and 2) and inducer fluorescence, it appears that wheat powdery mildew causes stronger responses than barley powdery mildew during the first approximately 10 hours after inoculation. This suggests that the primary germ tube is essential in the process of resistance induction. As the inducer fluorescence present 10 hours after inoculation is mainly situated at the primary germ tube, and as resistance induced by virulent barley powdery mildew and wheat powdery mildew only increases to a small extent after 10 hours of induction, it seems that this resistance mainly correlates with the inducer fluorescence at the primary germ tube.

\section{Localization of induced resistance}

In an attempt to assess the extension of induced resistance, inducer fluorescence was used to determine the previous location of the inducer (Thordal-Christensen and SMEdEGAARD-PEtersen in press, $b$ ). Three results are of importance: 1) No correlation between the infection success of the challenger and the average distance to the ten nearest inducer fluorescences could be detected. 2) Countings of the number of inducer fluorescences in the epidermal cells attacked by the challenger showed that successfully attacked epidermal cells contained only half the number of inducer fluorescences found in cells unsuccessfully attacked. 3) About one-third of the unsuccessful challenger infection units were attacking cells that contain no inducer fluorescence. In relation to (3) it is indicated above that a virulent race may have an infection efficiency of almost $100 \%$ when no resistance is activated by other infection units in the local leaf area (low inoculum density).

These results indicate that the induced resistance is principally localized to the cells attacked by the inducer, but it is to some extent also translocated to the epidermal cells not attacked by the inducer. This is consistent with the results of WoOlacott and Archer (1984), who found that infection units of virulent barley powdery mildew had a lower infection success when the primary germ tube previously had been in contact with the attacked barley leaf cell.

\section{Correlation between induced resistance and} host fluorescence at the site of the challenger

Thordal-Christensen and SmedegaARd-PETERSEN (in press, $b$ ) also studied the fluorescence at the challenger infection sites in relation to induced resistance. It was found that the diameters of the fluorescent papillae beneath unsuccessful challenger infection units were increased when resistance was induced in the leaf. The result agrees with the suggestion made by SAHASHi and Shishiyama (1986) that papilla formation at the challenger is a major factor of induced resistance. Further, the result supports the assumed importance of the papillae in the resistance process (e.g. KITA et al. 1980, Skou et al. 1984, Heitefuss and Ebrahim-Nesbat 1986, Smart et al. 1986).

It thus appears that resistance is induced, although no fluorescence or other host responses are visible in the microscope before challenge inoculation. This indicates that induced resistance is a state of sensitivity, where the resistance reaction is partially completed. 
The resistance reaction is fully expressed when the challenger is attacking. One of the major factors of this induced resistance could be the formation of larger papillae.

\section{Inducer removal versus no inducer removal}

Cho and SmedegaARd-Petersen (1986) found that resistance induced without removing the avirulent inducer race resulted in a fairly large number of visible necrotic spots, contrary to when the inducer race was removed. This indicates that resistance induction with and without inducer removal caused different types of resistance reactions. With inducer removal the resistance was expressed as a reduction in number of mildew colonies, while the resistance reaction without inducer removal furthermore includes a change in infection type towards an infection type with necrotic lesions.

\section{Significance of the primary germ tube}

KUNOH et al. (1978, 1982) investigated the incidence of host response at the primary germ tube. They found the first response to be host fluorescence at 2 to 3 hours after inoculation. The appearance of fluorescence was almost instantly followed by cytoplasmic aggregation, and later by papillae formation. These responses were found to have negative effect on the infection efficiency of the appressorium some hours later, where the primary germ tube and the appressorium were in contact with the same epidermal cell (Woolacott and Archer 1984). Cho and SmedegaArd-Petersen (1986) and ThordalChristensen and Smedegand-Petersen (in press, $a$ and in press, $b$ ) found that induced resistance could be detected as early as 1 hour after inoculation, and that the level of induced resistance seems to be proportional to the diameter of the host fluorescence beneath the primary germ tube of barley and wheat powdery mildew. These results suggest that the host response at the primary germ tube is essential to infection by barley powdery mildew. As the resistance induced by the nonhost pathogen, wheat powdery mildew, seems to be induced mainly by the primary germ tube, the interaction between this germ tube and the barley epidermal cell may be deleterious to the later infection attempt from wheat powdery mildew appressorium. The finding that the infection efficiency of virulent barley powdery mildew in a single inoculation procedure is reduced as inoculum density is increased, may also be a consequence of resistance induced by the primary germ tube.

\section{Conclusions of the work on induced resistance at our Department}

Both virulent and avirulent races of barley powdery mildew can induce resistance in double inoculation procedures, and a significant part of the resistance seems to be induced by the primary germ tube. In single inoculation procedures with virulent races this induction of resistance probably leads to infection failure. Thus, consistent with Fig. 2, the difference between virulent and avirulent races may be that avirulent races induce a small amount of resistance in addition to the level induced by virulent races, which then causes high rates of infection failures of the avirulent races.

Wheat powdery mildew induces most resistance shortly after inoculation, suggesting that a significant part of resistance in barley to wheat powdery mildew may be induced by the primary germ tube.

Induced resistance seems to be localized principally to the cells attacked by the inducer, but a significant part of the resistance is translocated to other epidermal cells.

One of the mechanisms of induced resistance is possibly an increased formation of fluorescent papillae at the challenger infection sites.

\section{Energetic consequences of active resistance on plant growth and yield}

Although disease resistance has proved in- 
valuable in plant breeding and plant production, research at our Department has shown that active defence processes in plants occur at the expense of the energy resources of the host and hence at the expense of yield.

Obviously resistance reactions are associated with enhanced biological activities including the accumulation of host-synthesized antimicrobial substances, synthesis and deposition of lignin-like materials, enhanced synthesis of postinfectional polypeptides, increases in certain hydrolytic enzymes such as chitinase, accumulation of hydroxyprolinerich glycoproteins and increased quantities of new mRNA species (Sequeira 1983, ManNers et al. 1985, Davidson et al. 1987).

That such resistance related increases in biosynthetic activity require considerable amounts of energy was demonstrated by comparing the respiration of incompatible and compatible interactions between barley and the barley powdery mildew fungus (SMEDEgaArd-Petersen and Stølen 1981, SmedeGAARD-PETERSEN 1982). After a single inoculation resistant leaves reacted with a rapid temporary respiratory increase, already detectable eight hours after inoculation, returning to the level of the non-inoculated control after three days. When plants were subjected to three successive inoculations spaced with intervals of two days, the oxygen uptake initially followed the same pattern but instead of returning to the normal level the rate stabilized at a level significantly higher than that of the noninoculated controls. Thus, repeated inoculation of barley with an avirulent race of the powdery mildew fungus causes a permanent increase in the rate of respiration. The pronounced increase in oxygen uptake coincided in time with the appearance of papillae beneath the appressoria (KUNOH et al. 1978), and the synthesis and accumulation of resistance related mRNA species and proteins (MANNERS et al. 1985, Davidson et al. 1987).

The high correlation between increases in oxygen uptake and synthetic activity indicated that the enhanced respiratory rate in incompatible barley powdery mildew interactions is part of energy-requiring biosynthetic processes, probably defence reactions, against the pathogen.

To investigate whether the increased energy demand in inoculated, resistant plants is sufficient to reduce plant yield, experiments were carried out in growth chambers (SMEDEGAARDPetersen and Stølen 1981). Although resistant plants did not show any visible disease symptoms after continuous inoculation with an avirulent race, the grain yield was significantly reduced by $7 \%$ and the kernel weight by $4 \%$. The yield of grain protein was reduced by $11 \%$ and straw length by $5 \%$.

The fact that highly resistant barley plants did not show any visible symptoms after inoculation with the pathogen does not, however, mean that the plants are not affected. The results suggest that mildew resistant barley plants respond to inoculation by energydemanding defence reactions that drain the stored host-energy otherwise available for build up of yield components.

Recent extensive studies (Tolstrup 1984, SmedegaArd-Petersen and Tolstrup 1985), have demonstrated that commonly occurring leaf saprophytes have the capacity for reducing crop yield by inducing energy-requiring defence reactions in much the same way as do incompatible races of powdery mildew. Leaf saprophytes are present in large amounts on the aerial parts of field crops where they colonize the lower dead leaves and deposit large quantities of spores on the upper green leaves. In general, these saprophytic leaf fungi are unable to infect vigorously growing green leaves, but the studies referred to above clearly suggest that saprophytic filamentous leaf fungi, especially species of Cladosporium, elicit active, energy-consuming defence reactions similar to those elicited by spores of avirulent barley powdery mildew. These reactions cause a drain of stored host energy, advanced senescence, and significantly less grain yield than would appear if these reactions did not happen. The yield-reducing effect of saprophytes is most marked in dense 
crops with a humid microclimate that promotes fungal growth and propagation.

\section{Induced resistance as a model for molecular studies of resistance}

The previous sections have indicated that induced resistance includes the same reactions as elicitation of the natural defence mechanisms of the plant.

With the use of biotically or abiotically induced resistance an excellent tool for the characterization of the plant response to treatments is available. Thereby the molecular genetics of the system can be investigated. In this context we are focusing on the resistance to barley powdery mildew induced either by the barley powdery mildew fungus itself or by non-host pathogenic fungi (CHO and SMEDEGAARD-PETERSEN 1986, Thordal-ChristenSEN and SmedegandD-Petersen in press, $a$ ).

These experiments are based on a double inoculation procedure as mentioned earlier. By following the changes in the gene expression of the plant in response to the inducing fungus, and observing the level of resistance induced it is possible to correlate the composition of the mRNA population to the level of resistance. Differences in the mRNA population between induced and non-induced lines of barley can be isolated and their occurrence investigated and quantified. These differences should also be compared to the changes observed during incompatible and compatible interactions conditioned by the presence or absence of resistance genes respectively. This is necessary in order to separate infection related responses occurring in both resistant and susceptible plant lines from resistance related responses occurring only in resistant lines. This is essential when considering the similarities between induced and resistance gene conditioned powdery mildew resistance.

Resistance, in the case of powdery mildew in barley is governed by resistance genes which are normally dominant and display a $3: 1$ ratio when crossed to a recessive allele partner.

It is observed in the case of powdery mildew on barley that also susceptible plants do display a fairly large degree of resistance when observing single penetration events. ANDERSEN and TORP (1986) found that on the susceptible line "Pallas» only around $30 \%$ of the conidia applied had formed ESH (Elongating Secondary Hyphae) $48 \mathrm{~h}$ after inoculation indicating a successful penetration event with a functional haustorium, compared to around $2 \%$ on the line with the Ml-a gene. When observing the development of the fungus on "Pallas", and the Ml-a line with the same gene background, it was seen that on both lines the most limiting stage was at penetration. Studies of the reactions in the plants have also shown that the penetration stage is the limiting stage and that the most significant reaction is the formation of papillae (BUSHNELl and BERGQUIST 1975, KUNOH et al. 1978, JoHnSON et al. 1979, Kita et al. 1980, KogA et al. 1980). The difference between the lines appears to a difference in the level of resistance rather than strictly resistance and susceptibility. The resistance genes can then be called regulatory loci amplifying the response over the level seen in susceptible plants (BENNETZEN 1984).

Considering the induction of resistance in susceptible plants, we are able to simulate the presence of a resistance gene and trigger a resistant response indiscernible from the response when a resistance gene is present. This indicates that the susceptible plant also contains all the genetic information needed to express resistance at a level comparable to the resistant line. Only the initial triggering appears to be different. The resistance gene can then be postulated to be responsible for the triggering in the genetically resistant line.

It seems that the interaction with the fungus is controlled by interaction with both primary gene products exerting an effect on the expression of resistance or being effective on their own, and the secondary metabolism of the plant (formation of physical and chemical compounds having an effect on the pathogen). 
Primary gene products involved in resistance

Constitutively expressed. Due to the lack of precise information on how the elicitation of resistance actually takes place, certain assumptions must be made.

1) It is reasonable to assume that plants contain sensing mechanisms that are able to detect attacking organisms or elicitating compounds in the cell environment, and start countermeasures against ingress of the pathogen.

2) It is also plausible that the sensing mechanisms at least to some extent are able to distinguish between fungi. In the case of the most specialized systems to which the powdery mildew in barley belongs, a level of fungal race/host gene specific interaction exists that is essential for the final expression of resistance (Ellingboe 1972).

At least part of this sensor/trigger system needs to be present at all times in the plant, and therefore the gene(s) involved very likely are constitutively expressed. Whether there is induced expression of additional genes or the expression of the system as a whole is increased when resistance is induced or a resistance gene controlled incompatible interaction develops, is not known.

Investigations on the molecular genetics of the sensing process and triggering of resistance should be performed using non-inoculated plants, due to at least two reasons. Firstly, one should expect that the constitutive level of expression of the resistance gene is low considering that there are probably many systems for the pathogens the plants are in contact with. The energy demand on the plant would be large if a high level of expression was to be maintained. Secondly, using inoculated plants the bulk of changes in gene expression is very likely to mask subtle differences between lines mediated by the presence of resistance genes.

The response to infection after induction of resistance in susceptible plants appears indiscernible from the response when a resistance gene is present. How far these similarities extend when we study the induced resistance at the level of gene expression is not known, but most of the observable responses are derived from secondary metabolism in the plant (see next section).

Induced expression of PR-proteins. Many dicotyledonous plants have been reported to produce a special class of proteins as a response to viral infection. These proteins occurred at the time of hypersensitive necrosis formation and are characterized by low molecular weight $(15-20 \mathrm{kD})$, solubility at low $\mathrm{pH}$, protease resistance and their presence in the intercellular space in cells undergoing hypersensitive collapse (VAN LoON 1985). The proteins have been called pathogenesis-related (PR) proteins, as they appeared to be more involved in the general response to pathogenic conditions than in the expression of resistance as such. A role has been proposed in hypersensitive collapse reactions, but no proof has been presented (VAN LOON 1985).

Until recently these proteins were considered to be unique to dicotyledonous species responding to viral infection, but recent studies at Rothamsted have shown the presence of PRproteins in barley undergoing hypersensitive collapse reactions (WHITE et al. 1987). That is a reaction in a monocotyledonous plant to a fungus.

Until recently no biochemical function could be suggested for these proteins, but RICHARDSON et al. (1987) have observed homology between a maize protein that inhibits bovine trypsin and $\alpha$-amylase in vitro and a tobacco PR-protein. PR-protein-like compounds have also been found in wounded tomato plants after squeezing the leaf blade. These proteins had a molecular weight of only around half the average molecular weight of the tobacco PR-proteins, but they also possessed a strong inhibitory effect on proteinases (GrAHAM et al. 1985). These proteins occurred in leaves that were undergoing collapse reactions in order to limit the wounded area from the healthy leaf area. This somewhat extends the definition of PR-proteins as only being involved in pathogenesis to rather being involved in collapse reactions more generally. 
If the PR-proteins were to be assigned a function in protein/protein interaction it would make sense in many respects. The synthesis and transport to the intercellular space results in inhibition of an intercellular, cell wall or outer membrane protein essential for the function of the cellular membrane resulting in loss of electrolytes from the cell ending with death of the cell (VAN LoON 1985).

\section{Secondary metabolism involved in resistance}

Resistance to powdery mildew is observed in the plant cell as a sequence of responses.

The first visible reaction is the formation of a cytoplasmatic aggregate with a papilla at the site of the primary germ tube as observed by KunOH et al. (1982). This papilla may also contain substances that fluoresce in UV light (KunOH et al. 1982). The second visible reaction is the formation of similar structures at appressorial germ tubes at the site of penetration attempts (BUSHNELL and BERGQUisT 1975, Aist and Israel 1977). The presence of substances fluorescing under UV-light in these papillae seems to enhance the level of resistance to penetration (KITA et al. 1980, KogA et al. 1980). The fluorescence is initially limited to the papilla and the surrounding halo, but in case of penetration of the papilla the fluorescence of the papilla can spread all over the plant cell, followed by disintegration (hypersensitive collapse) of the host cell, leading to death of the host cell (JoHNSON et al. 1979, KogA et al. 1980, KitA et al. 1981).

Studies of different powdery mildew resistance genes have shown that the fluorescence of whole cells and host cell collapse is a common phenomenon in particular in postpenetration events (KogA et al. 1980). These authors showed that the later the collapse reactions started, the more cells were affected. This was also found by ANDERSEN and JIANG (1984), who furthermore reported intense reactions in the mesophyll leading to both visible chlorosis and necrosis in the case of the resistance genes Ml-p and Ml-(1402).
Unfortunately very little is known about the pathways of secondary metabolism in barley. The papillae have been shown to contain lignin in wheat (RIDE and PEARCE 1979), but not in barley (SMART et al. 1986). SMART et al. (1986) failed to detect any suberin deposition in papillae. Lignin and suberin obtain the main part of their monomers from the shikimic acid pathway, but also the information on the enzymes frequently reported to be stimulated in dicotyledonous plants are very limited in barley. Suberin furthermore contains a large fraction of fatty acids, presumably mobilized from an endogenous pool.

Callose has been demonstrated in barley papillae by SMART et al. (1986) and SKOU (1982). The key enzyme in callose deposition is UDP glucose: glucan synthetase whose product is $\beta 1-3$ glucans. Very scarce information is available on this enzyme, and nothing is to our knowledge published on barley. The articles reporting on the presence of callose in papillae do not go into deeper studies of the biochemistry of papilla formation.

In the barley/powdery mildew system no fungitoxic (phytoalexins) compounds have been identified, although initial reports by Оки and Оuсні (1976) and ОкU et al. (1975) have been addressing the subject. They obtained results from exudates of inoculated leaves stating that substances having an inhibitory effect on the germination of powdery mildew conidia were present in the plant, with a peak of activity in incompatible interactions around $12 \mathrm{~h}$ after inoculation. These substances have not to our knowledge been dealt with further, but the occurrence of phytoalexins from other cereals have been reported after these results were published. In rice the momilactones ( $\mathrm{A}$ and $\mathrm{B}$ ) were identified by CARTwright et al. (1977) and in oats the avenalumins was identified by MAYAMA et al. (1981).

These substances are not derivatives of the shikimic acid pathway indicating that this pathway has a lower significance in cereals than in the dicotyledonous species mostly studied. 
Comparing this with what was reported on the chemically induced resistance in rice (Oryza sativa) to the rice blast fungus (Pyricularia oryzae) by applying compounds of the dichlorocyclopropane group might give some information on the reactions taking place in barley. These investigations showed some characteristic features in the treated plants before inoculation. Treated plants had peroxidase activities 12 times higher than non-treated plants, IAA-oxidase activity 1.7 times higher and catalase 0.5 times the activity of nontreated plants (LANGCAKE and WiCKINS 1975). These authors reported that they found no changes in PAL, TAL and $\beta$-galactosidase in response to treatment neither before nor after inoculation.

These changes were apparently sufficient to condition the susceptible rice cultivar to be resistant and resulted in a much faster formation of brown pigment, said to be melanin (LANGCAKE and WiCKINS, 1975), although the main monomer of melanin (catechol) could not be shown before inoculation.

It is significant to note that these authors did not observe any visible symptoms in the plants after treatment (LANGCAKE and WiCKINS, 1975), which corresponds to our failure to observe any changes in the cells, such as diffuse cellular fluorescence, after induction (THORDAL-Christensen and SMedegaARd-Petersen, in press, $b$ ).

Hislop and Stahmann (1971) reported that the activity of peroxidase increased in a range of host lines tested after inoculation with the barley powdery mildew fungus. The increase was observed in both compatible and incompatible interactions, being slightly greater at 24 hours after inoculation in incompatible interactions. The pattern of peroxidase increase during the first 24 hours followed the same line in both compatible and incompatible interactions, and comparing to induced resistance it follows the trend of the data presented in Fig. 2, with the avirulent and virulent isolate being equally efficient as resistance inducers before $10-12$ hours after inoculation and the avirulent isolate being best at induction periods longer than 12 hours.

This is no evidence for the involvement of peroxidase in induced resistance, but it is suggested that peroxidase could be used as a marker enzyme for the biochemical and molecular studies of resistance. Much knowledge is lacking on other enzyme systems being involved in the response to fungal infection. The studies of the gene expression associated with induced resistance and resistance gene conferred resistance are just beginning, and hopefully we will be able to employ and combine the new technology with the current knowledge to get a more complete picture of the genetic machinery involved in resistance.

\section{Transgenic plants with improved resistance}

For the purpose of making transgenic plants with improved resistance a number of factors need to be resolved before success is to be expected. First of all, our transformation systems need to be improved, but in the light of recent developments on cereal transformation such possibilities may have improved (DE LA PeÑa et al. 1987). Second, we need to localize and characterize the sensor/trigger system and to study the molecular mechanisms in its function. Third, we must try to modulate the effect to give an improved effect against more races of the pathogen and a better amplification of the resistant response, and fourth, we need to know more about the complex mechanisms regulating the resistant response in the later stages. 


\section{Literature}

Aist, J.R. \& Israel, H.W. 1977. Papilla formation: Timing and significance during penetration of barley coleoptiles by Erysiphe graminis hordei. Phytopathology 67: $455-461$.

ANDERSEN, B. 1983. Induced resistance to barley powdery mildew. Acta Agric. Scand. 33: 269-271.

Andersen, J.B. \& TorP, J. 1986. Quantitative analysis of the early powdery mildew infection stages on resistant barley genotypes. J. Phytopathology 115: 173-186.

Andersen, J.B. \& JiAng, W.M. 1984. The response of four barley lines to powdery mildew infection. Nord. Jordbrugsforsk. 66: 356-358.

Anderson, A.J. 1980. Differences in the biochemical compositions and elicitor activity of extracellular components produced by three races of fungal plant pathogen, Colletotrichum lindemuthianum. Can. J. Microbiol. 26: 1473-1479.

Ayers, A.R., Ebel, J., Valent, B.S. \& Albersheim, P. 1976. Host pathogen interaction X. Fractionation and biological activity of an elicitor isolated from the mycelial walls of Phytophthora megasperma var. sojae. Plant Physiol. 57: 760-765.

Bennetzen, J.L. 1984. Genetic engineering for improved crop disease resistance. In: Applications of Genetic Engineering to Crop Improvement. Eds., Collins G.B. \& Petolino J.G. pp. 491-524. Martinus Nijhoff, Dordrecht.

Bostock, R.M., Kuc, J.A. \& LAINE, R.A. 1981. Eicosapentaenoic and arachidonic acids from Phytophthora infestans elicit fungitoxic sesquiterpenes in the potato. Science 212: 67-69.

Bushnel., W.R. \& Bergquist, S.E. 1975. Aggregation of host cytoplasm and the formation of papillae and haustoria in powdery mildew of barley. Phytopathology 65: 310-318.

Bruce, R.J. \& West, C.A. 1982. Elicitation of caspene synthetase activity in castor bean. The role of pectic fragments of the plant cell wall in elicitation by fungal endopolygalacturonase. Plant Physiol. 69: 1181-1188.

Cartwright, D., Langcake, P., Pryce, R.J., Leworthy, D.P. \& RiDE, J.P. 1977. Chemical activation of host defence mechanisms as a basis for crop protection. Nature 267: 511-513.

Chaudhary, R.C., Schwarzbach, E. \& Fischbeck, G. 1983. Quantitative studies of resistance induced by avirulent cultures of Erysiphe graminis f.sp. hordei in barley. Phytopath. Z. 108: 80-87.

Chal, H.B. \& Doke, N. 1987. Superoxide anion generation: A response of potato leaves to infection with Phytophthora infestans. Phytopathology 77: 645-649.

Chin, K.M., Wolfe, M.S. \& Minchin, P.N. 1984. Hostmediated interactions between pathogen genotypes. Plant Pathology 33: 161-171.

Cho, B.H. \& SmedegaARd-Petersen, V. 1986. Induction of resistance to Erysiphe graminis f.sp. hordei in nearisogenic barley lines. Phytopathology 76: 301-305.
Darvill, A.G. \& Albersheim, P. 1984. Phytoalexins and their elicitors - A defense against microbial infection in plants. Ann. Rev. Plant Physiol. 35: 243-275.

Davidson, A.D., Manners, J.M., Simpson, R.S. \& Scott, K.J. 1987. cDNA cloning of mRNAs induced in resistant barley during infection by Erysiphe graminis f.sp. hordei. Plant Molecular Biology 8: 77-85.

Davis, K.R., Darvill, A.G. \& Albersheim, P. 1986. Hostpathogen interactions XXXI. Several biotic and abiotic elicitors act synergistically in the induction of phytoalexin accumulation in soybean. Plant Molecular Biology 6: 23-32.

De La Peña, A., Lorz, H. \& Schell, J. 1987. Transgenic rye plants obtained by injecting DNA into young floral tillers. Nature 325: 274-276.

De Wit, P.J.G.M., BuUralge, M.B. \& Hammond, K.E. 1986. The occurrence of host-, pathogen- and interaction-specific proteins in the apoplast of Cladosporium fulvum (Sun. Fulvia fulva) infected tomato leaves. Physiological and Molecular Plant Pathology 29: 159-172.

DOKE, N. 1983. Involvement of superoxide anion generation in the hypersensitive response of potato tuber tissues to infection with an incompatible race of Phytophthora infestans and to the hyphal wall components. Physiological Plant Pathology 23: 345-357.

Doke, N., Chal, H.B. \& Kawaguchi, A. 1987. Biochemical basis of triggering and suppression of hypersensitive cell response. In: Molecular Determinants of Plant Diseases. Eds., Nishimura S., Vance C.P. \& Doke, N. pp. 235-251. Japan Sci. Soc. Press, Springer Verlag, Tokyo, Berlin.

Doke, N., Garas, N.A. \& Kuc, J. 1979. Partial characterization of the mode of action of a hypersensitivityinhibiting factor (HIF) isolated from Phytophthora infestans. Physiological Plant Pathology 15: 127-140. EllingBoE, A.H. 1972. Genetics and physiology of primary infection by Erysiphe graminis. Phytopathology 62: 401-406.

EllingBoE, A.H. 1982. Genetical aspects of active defense. In: Active Defense Mechanisms in Plants. Ed., R.K.S. Wood, pp. 179-192. Plenum Press, New York.

Epperlein, M.M., Noronhad, A.A. \& Strange, R.N. 1986. Involvement of the hydroxyl radical in the abiotic elicitation of phytoalexin in legumes. Physiological and Molecular Plant Pathology 28: 67-77.

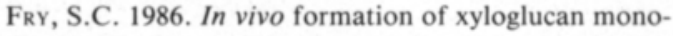
saccharide: A possible biologically active cell-wall fragment. Planta 169: 443-453.

Graham, J.S., Pearce, G., Merryweather, J., Titani, K., Ericsson, L. \& Ryan, C.A. 1985. Wound-induced proteinase inhibitors from tomato leaves. I. The cDNAdeduced primary structure of pre-inhibitor I and its post-translational processing. J. Biol. Chem. 260: $6555-6560$. 
Hahn, M.G., Darvill, A.G. \& Albersheim, P. 1981. Host-pathogen interactions. XIX. The endogenous elicitor, a fragment of a plant cell wall polysaccharide than elicits phytoalexin accumulation in soybeans. Plant Physiol. 68: 1161-1169.

Hargreaves, J.A. \& Bailey, J.A. 1978. Phytoalexin production by hypocotyls of Phaseolus vulgaris in response to constitutive metabolites released by damaged bean cells. Physiological Plant Pathology 13: 89-100.

Heitefuss, R. \& Eвrahim-Nesbat, F. 1986. Ultrastructural and histochemical studies on mildew of barley (Erysiphe graminis DC. f.sp. hordei Marchal) III. Ultrastructure of different types of papillae in susceptible and adult plant resistant leaves. J. Phytopathology 116: 358-373.

Hislop, E.C. \& Stahmann, M.A. 1971. Peroxidase and ethylene production by barley leaves infected with Erysiphe graminis f.sp. hordei. Physiological Plant Pathology 1: 297-312.

Johnson, L.E.B., Bushnell, W.R. \& Zeyen, R.J. 1979. Binary pathways for analysis of primary infection and host response in populations of powdery mildew fungi. Can. J. Bot. 57: 497-511.

KEEN, N.T. 1982. Mechanisms conferring specific recognition in gene-for-gene plant paratite systems. In: Active Defense Mechanisms in Plants. Ed. Wood R.K.S., pp. 67-84. Plenum Press, New York.

KeEn, N.T. \& Legrand, M. 1980. Surface glycoproteins: evidence that they may function as the race specific phytoalexin elicitor of Phytophthora megasperma f.sp. glycinea. Physiological Plant Pathology 17: 175-192.

Keen, N.T. \& Yoshikawa, M. 1983. $\beta$-1,3-endoglucanase from soybean releases elicitor-active carbohydrates from fungus cell walls. Plant Physiol. 71: 460-465.

Kita, N., Toyada, H. \& Shishiyama, J. 1981. Chronological analysis of the cytological responses in powderymildewed barley leaves. Can. J. Bot. 59: 1761-1768.

Kita, N., Toyoda, H., Yano, T. \& Shishiyama, J. 1980. Correlation of fluorescent appearance in papilla with unsuccessful penetration attempts in susceptible barley inoculated with Erysiphe graminis f.sp. hordei. Ann. Phytopath. Soc. Japan 46: 594-597.

Koga, H., Mayama, S. \& Shishiyama, J. 1980. Correlation between the deposition of fluorescent compounds in papillae and resistance in barley against Erysiphe graminis hordei. Can. J. Bot. 58: 536-541.

Kunoh, H., Hayashimoto, A., Harui, M. \& Ishizaki, H. 1985. Induced susceptibility and enhanced resistance at the cellular level in barley coleoptiles. I. The significance of timing of fungal invasion. Physiological Plant Pathology 27: 43-54.

Kunoh, H., Tsuzukı, T. \& IshizaKı, H. 1978. Cytological studies of early stages of powdery mildew in barley and wheat. IV. Direct ingress from superficial primary germ tubes and appressoria of Erysiphe graminis hordei on barley leaves. Physiological Plant Pathology 13: 327-333.
Kunoh, H., Yamamorı, K. \& Ishizakı, H. 1982. Cytological studies of early stages of powdery mildew in barley and wheat. VIII. Autofluorescence at penetration sites of Erysiphe graminis hordei on living barley coleoptiles. Physiological Plant Pathology 21: 373379.

LAngcake, P. \& Wickins, S.G.A. 1975. Studies of the action of the dichlorocyclopropanes on the host-parasite relationship in the rice blast disease. Physiological Plant Pathology 7: 113-126.

Manners, J.M., Davidson, A.D. \& Scott, K.J. 1985. Patterns of post-infectional protein synthesis in barley carrying different genes for resistance to powdery mildew fungus. Plant Molecular Biology 4: 275-283.

Mayama, S., Tani, T. \& Matsuura, Y. 1981. The production of phytoalexins by oat in response to crown rust, Puccinia coronata f.sp. avenae. Physiological Plant Pathology 19: 217-226.

Mayama, S., Tani, T., Ueno, T., Midland, S.L., Sims, J.J. \& KeEN, N.T. 1986. The purification of victorin and its phytoalexin elicitor activitor in oat leaves. Physiological and Molecular Plant Pathology 29: 1-18.

Ocampo, C.A., Moerschbacher, B. \& Grambour, H.J. 1986. Increased lipoxygenase activity is involved in the hypersensitive response of wheat leaf cells infected with avirulent rust fungi or treated with fungal elicitor. $\mathbf{Z}$. Naturforsch. 41: 559-563.

ОкU, H. \& Ouchı, S. 1976. Host plant accessibility to pathogens. Rev. Plant Protec. Res. 9: 58-71.

Окu, Н., Оuchi, S., Shiraishi, Т., Комото, Y. \& Окı, K. 1975. Phytoalexin activity in barley powdery mildew. Ann. Phytopath. Soc. Japan 41: 185-191.

Oисні, S., Окч, Н. \& Hıвınо, С. 1976. Localization of induced resistance and susceptibility in barley leaves inoculated with the powdery mildew fungus. Phytopathology 66: 901-905.

Ouchi, S., Oкu, H., Нıвıno, C. \& Akıyama, I. 1974. Induction of accessibility and resistance in leaves of barley by some races of Erysiphe graminis. Phytopath. Z. 79: $24-34$.

Preisig, C.L. \& Kuc, J.A. 1985. Arachidonic acidrelated elicitors of the hypersensitive response in potato and enhancement of their activities by glucans from Phytophthora infestans (Mont.) deBary. Archives of Biochemistry and Biophysics 236: 379-389.

RaA, J., Robertsen, B., Solheim, B. \& Tronsmo, A. 1977. Cell surface biochemistry related to specificity of pathogenesis and virulence of microorganisms. In: Cell Wall Biochemistry Related to Specificity in Host-Plant Pathogen Interactions. Eds., Solheim B. \& Raa J., pp. 11-28. Universitetsforlaget, Oslo.

Richardson, M., Valdes-Rodrigues, S. \& Blanco-Labra, A. 1987. A possible function of for thaumatin and TMV-induced protein suggested by homology to a maize inhibitor. Nature 327: 432-434.

Ride, J.P. \& Pearce, R.B. 1979. Lignification and papillae formation at sites of attempted penetration of 
wheat leaves by nonpathogenic fungi. Physiological Plant Pathology 15: 79-92.

Rohwer, F., Fritzemeier, K.-H., Scheel, D. \& HahlBROCK, K. 1987. Biochemical reactions of different tissues of potato (Solanum tuberosum) to zoospores or elicitors from Phytophthora infestans. Accumulation of sesquiterpenoid phytoalexins. Planta 170: 556-561.

Sahashi, N. \& Shishiyama, J. 1986. Increased papillae formation, a major factor of induced resistance in the barley - Erysiphe graminis f.sp. hordei system. Can. J. Bot. 64: 2178-2181.

SequeIRA, L. 1983. Mechanisms of induced resistance in plants. Ann. Rev. Microbiol. 37: 51-79.

Sharp, J.K., Valent, B. \& Albersheim, P. 1984. Purification and partial characterization of a $\beta$-glucan fragment that elicits phytoalexin accumulation in soybean. $\mathbf{J}$. Biol. Chem. 259: 11312-11320.

Skou, J.P. 1982. Callose formation responsible for the powdery mildew resistance in barley genes in the $\mathrm{ml}-\mathrm{o}$ locus. Phytopath. Z. 104: 90-95.

Skou, J.P., Jergensen, J.H. \& Lilholt, U. 1984. Comparative studies on callose formation in powdery mildew compatible and incompatible barley. Phytopath. Z. 109: $147-168$.

Smart, M.G., Aist, J.R. \& Israel, H.W. 1986. Structure and function of wall appositions. 2. Callose and the resistance of oversize papillae to penetration by Erysiphe graminis f.sp. hordei. Can. J. Bot. 64: 802-804.

SmedegaArd-Petersen, V. 1982. The effect of defence reactions on the energy balance and yield of resistant plants. In: Active Defense Mechanisms in Plants. Ed., Wood R.K.S., pp. 299-315. Plenum Press, New York.

SmedegaArd-Petersen, V. \& Stølen, O. 1981. Effect of energy-requiring defense reactions on yield and grain quality in a powdery mildew-resistant barley cultivar. Phytopathology 71: 396-399.

Smedegandd-Petersen, V. \& Tolstrup, K. 1985. The limiting effect of disease resistance on yield. Ann. Rev. Phytopathol. 23: 475-490.
Stelzig, D.A., Allen, R.D. \& Bhatia, S.K. 1983. Inhibition of phytoalexin synthesis in arachidonic acidstressed potato tissue by inhibitors of lipoxygenase and cyanide-resistant respiration. Plant Physiol. 72: 746749.

Tepper, C.S. \& Anderson, A.J. 1986. Two cultivars of bean display a differential response to extracellular components from Colletotrichum lindemuthianum. Physiological and Molecular Plant Pathology 29: 411-420.

Thordal-Christensen, H. \& Smedegaard-Petersen, V. Comparison of resistance inducing abilities of virulent and avirulent races of Erysiphe graminis f.sp. hordei and one race of Erysiphe graminis f.sp. tritici in barley. Plant Pathology (in press, a).

Thordal-Christensen, H. \& Smedegandd-Petersen, V. Correlation between induced resistance and host fluorescence in barley inoculated with Erysiphe graminis. J. Phytopathology (in press, b).

ToLSTRUP, K. 1984. Saprophytic fungi in the phyllosphere of barley and their effects on the plant growth and grain yield. PhD thesis. R. Vet. Agric. Univ., Copenhagen. $122 \mathrm{pp}$.

VAN LoON, L.C. 1985. Pathogenesis - related proteins. Plant Molecular Biology 4: 111-116.

White, R.F., Rybicki, E.P., Von Wechmar, M.B., DekKER, J.L. \& ANTONIW, J.F. 1987. Detection of PR 1-type proteins in Amaranthaceae, Chenopodiaceae, Graminae and Solanaceae by immunoelectroblotting. J. Gen. Virol. 68: 2043-2048.

Woolacott, B. \& Archer, S.A. 1984. The influence of the primary germ tube on infection of barley by Erysiphe graminis f.sp. hordei. Plant Pathology 33: 225-231.

Yoshikawa, M., Keen, N.T. \& Wang, M.-C. 1983. A receptor on soybean membranes for a fungal elicitor of phytoalexin accumulation. Plant Physiol. 73: 497-506.

Ms received August 19, 1987 


\section{SELOSTUS}

\section{Kasvin puolustusmekanismien aktivoituminen}

Hans Thordal-Christensen, Per L. Gregersen, Jan B. Andersen ja Viggo Smedegaard-Petersen

Department of Plant Pathology, The Royal Veterinary and Agricultural University, Thorvaldsensvej 40, 1871 Frederiksberg C, Copenhagen, Denmark

Katsauksessa tarkastellaan kasvien indusoituvaa resistenssiä. Se perustuu fysikaalisiin ja kemiallisiin mekanismeihin, jotka alkavat toimia patogeenin tai saprofyytin aiheuttaman infektion tai näiden aineenvaihduntatuotteiden vaikutuksesta. Indusoituvan resistenssin ja kasvin normaalin taudinkestävyyden perusmekanismit lienevăt samankaltaiset. Indusoituvan resistenssin aktivoivat elisitorit, kemialliset aineet, joita on eristetty useista sienipatogeeneistă ja kasvin soluseinăstä. Useimmat elisitorit ovat epăspesifisiă ja vain muutamat spesifisiä eli aktivoivat vain tiettyjen lajikkeiden resistenssin. Toistaiseksi ei tiedetä, miten elisitorien laukaisema viesti välittyy kasvisolun reseptoriin ja saa resistenssimekanismit toimimaan.

Tanskan maatalouskorkeakoulun kasvipatologian laitoksella tutkitaan ohran indusoituvaa härmäresistenssiä.
Sekă virulentit ettă ei-virulentit isolaatit indusoivat resistenssin mutta ei-virulenttien aikaansaama resistenssi on alkuvaiheessa tehokkaampaa. Vehnän härmäisolaatti indusoi ohrassa voimakkaamman resistenssin kuin vastaava ohran isolaatti. Indusoituva resistenssi paikallistuu pääasiassa infektiokohdan epidermisoluihin mutta se voi ilmetä myös infektiokohdan ympäristössä.

Härmäresistenssi lisăä kasvin energian tarvetta, minkă on havaittu pienentävăn ohran jyväsatoa noin $7 \%$. Resistenssi perustuu yksittäisiin major-geeneihin ja sen ilmenemiseen liittyy lähetti RNA:n ja proteiinien synteesiä. Nykyisen molekyylibiologian, erityisesti yhdistelmäDNA -tekniikan, avulla voidaan tutkia indusoituvan resistenssin molekulaarista perustaa, aktivoitumista ja ilmenemistã, mikă ei aiemmin ole ollut mahdollista. 